\title{
Economics of a Hairy Vetch Mulch System for Producing Fresh-market Tomatoes in the Mid-Atlantic Region
}

\author{
Terry C. Kelly', Yao-Chi Lu', Aref A. Abdul-Baki ${ }^{3}$, and John R. Teasdale \\ United States Department of Agriculture, Agricultural Research Service, Beltsville Area Research Center, \\ 10300 Baltimore Avenue, Beltsville, MD 20705 \\ Additional index words. sustainable agriculture, organic mulch, black polyethylene, vegetable, marketing, risk, safety-first, \\ Vicia villosa, Lycopersicon esculentum

\begin{abstract}
Concern for the environment has focussed attention on the need for environmentally sound, yet economically profitable, farming practices. A hairy vetch (Vicia villosa L. Roth.) organic mulch system for fresh-market tomato (Lycopersicon esculentum Mill.) production provides environmental benefits by enhancing the soil and reducing the need for fertilizer and herbicide inputs and is more profitable than conventional practices. Tomato field trials over 3 years at the Beltsville (Md.) Agricultural Research Center compared the hairy vetch mulch system with black polyethylene mulch and bare ground (no mulch). Using partial budget analysis in a farm context, the hairy vetch mulch treatment was more profitable in all years under all market and yield adjustment scenarios. The vetch mulch system also was the preferred system for a risk-averse grower, according to a safety-first criterion. The combination of environmental benefits and the economic benefits to the grower make the hairy vetch mulch system an attractive alternative for producing fresh-market tomatoes in the Mid-Atlantic and parts of northeastern United States.
\end{abstract}

Small farms are an important and growing segment of U.S. agriculture, particularly in the Northeast (Butte1 et al., 1988; Teasdale and Colacicco, 1985), and this segment is becoming increasingly dominated by small and part-time operators. Among these operators, vegetable production is a common enterprise, and tomatoes are among the most frequently produced and profitable vegetable crops for small farms. In some parts of the northeastern and mid-Atlantic regions, tobacco has historically been the mainstay for small farms, with very small holdings providing the main and stable income for the farms. However, future uncertainties with tobacco production threaten many small farmers as tobacco acreage dwindles. For example, tobacco acreage in southern Maryland decreased from 50,000 in 1950 to 25,000 in 1982, and to only 9,000 in 1993 (James C. Hanson, personal communication). On such small holdings, vegetable production is perhaps the only viable alternative.

The recent emphasis on health and environmental concerns in agriculture also favors vegetable production. People are encouraged to eat more vegetables for their nutrition and claimed properties of reducing risks of heart problems and cancer. Demand for fruit and vegetables in the United States has risen recently as a result of renewed health consciousness, increasing $22 \%$ during the 1980s [U.S. Dept. of Agriculture (USDA), 19921. Vegetable

Received for publication 11 Oct. 1994. Accepted for publication 20 Apr. 1995. Florida Agricultural Experiment Station Journal series no. R-04509. We acknowledge the assistance of James C. Hanson, extension economist, Univ. of Maryland, who provided price data for the Southern Maryland Regional Farmers' Market, Cheltenham, Md. We appreciate comments from James Hanson, Wen-Yuang Huang, Dale Johnson, and Charles McClurg. Mention of a trademark, proprietary product, or vendor is not a guarantee or warranty by the U.S. Dept. of Agriculture and does not imply its approval to the exclusion of other products or vendors that also may be suitable. The cost of publishing this paper was defrayed in part by the payment of page charges. Under postal regulations, this paper therefore must be hereby marked advertisement solely to indicate this fact.

'Food and Resource Economics Dept., Univ. of Florida, Gainesville; visiting scientist in the Systems Research Laboratory.

${ }^{2}$ Systems Research Laboratory.

${ }^{3}$ Vegetable Laboratory.

${ }^{4}$ Weed Science Laboratory. production also fares well under alternative, more sustainable production practices. Whereas grain yields often decline under organic and low-input production practices, at least during the transition stage (Lu and Kelly, 1995), vegetable yields tend to remain high when grown organically (Univ. of California, 1993). The high management requirement that characterizes vegetable production fits in well with the management-intensive nature of sustainable agriculture.

Concern for the environment is a driving force behind sustainable agriculture and the impetus for renewed interest in leguminous organic mulch systems. Environmental benefits provided by organic mulches include reduced soil erosion, reduced need for inorganic nutrient amendments, improved soil organic content, increased soil water-holding capacity, and reduced weed competition and need for herbicides (Abdul-Baki and Teasdale, 1993). In addition, however, for agriculture to be sustainable, it must be productive and provide farmers with an adequate and stable income. Environmentally friendly farming practices that reduce farm incomes are very hard to sell to farmers and tend not to be adopted. Profitability is an important component of any viable sustainable practice. This paper investigates the economics of an alternative hairy vetch organic mulch system for fresh-market tomato production relative to more traditional black polyethylene mulch and no-mulch (bare soil) systems.

\section{Materials and Methods}

Field experiments. The experiments were conducted over 3 years, 1991-93, at the Beltsville (Md.) Agricultural Research Center on Keyport fine sandy loam soil (clayey, mixed, mesic Aquic Hapludult) with $2 \%$ slope. Two mulch systems, hairy vetch and black polyethylene, were compared with a no-mulch (bare soil) system. The 1991 experiment is described in detail by AbdulBaki and Teasdale (1993). The experiments in all 3 years included additional treatments that are not included in the analyses in this paper.

Beds $1.5 \mathrm{~m}$ wide center to center and $15 \mathrm{~cm}$ high were prepared. Each mulch treatment was randomly assigned to beds, with four to 
eight beds per treatment, depending on the year. Tomato plants were transplanted by hand in 1991 and 1992 and by machine in 1993 during early May. Plant spacing within the beds varied slightly from year to year, ranging from 0.5 to $0.6 \mathrm{~m}$.

Hairy vetch seed was sown in freshly prepared beds at the rate of $53 \mathrm{~kg} \cdot \mathrm{ha}^{-1}$ in mid-September. The plants received no water or any other treatments until they were mowed in early May before transplanting tomatoes. The plots were mowed about 3 to $5 \mathrm{~cm}$ above the bed's surface using a high-speed flail mower to kill the vetch and form a uniform layer of organic mulch 5 to $8 \mathrm{~cm}$ thick. Beds for the black polyethylene and bare soil were prepared during late April as described by Abdul-Baki et al. (1992).

Fresh-market 'Sunny' tomato seeds were obtained from a commercial source. Seeds were started in a greenhouse in 72-cell flats (cell size $4 \times 4 \times 6 \mathrm{~cm}$ ) filled with Jiffy Mix Plus (Jiffy Products, Batavia, Ill.), a mixture of $50 \%$ peat and $50 \%$ horticultural- vermiculite (w/w) supplemented biweekly with starter fertilizer (Peters 20N-8.8P-16.6K; Grace Sierra Horticultural Products, Milpitas, Calif. at $37 \mathrm{~g} \cdot$ liter $^{-1}$ water. The seedlings were kept for 4 weeks in a greenhouse and 1 week in a cold frame. The tomato transplants for all systems were field-planted on the same dates. Peters starter fertilizer was applied at $37 \mathrm{~g} \cdot \operatorname{liter}^{-1}$ water on all plants immediately after planting. Trickle irrigation lines were laid over the cut mulch surface $10 \mathrm{~cm}$ away from the plants and fixed in position with U-shaped wires in the vetch system, and below the soil surface in the black polyethylene and bare-soil systems. In 1991, fertilizer (9N-6.6P-24.9K) was applied weekly from transplant through the first week in August via the trickle system at 52 $\mathrm{kg} \cdot \mathrm{ha}^{-1}$ for the polyethylene and no-mulch systems and biweekly at the same rate for the vetch mulch system. In 1992 and 1993, nitrogen fertilizer was applied in the same manner as in 1991 , but at $112 \mathrm{~kg} \mathrm{~N} / \mathrm{ha}$ for the bare-soil and black polyethylene systems and $56 \mathrm{~kg} \mathrm{~N} / \mathrm{ha}$ in the vetch mulch system. The difference in rates is due to the nitrogen contribution of the hairy vetch. Based on soil tests, no P or K was applied in 1992 and 1993. Tomatoes were supported using the stake-and-weave system.

Weeds were controlled the first year in the bare-soil and black polyethylene systems with a pre-plant-incorporated herbicide application of $2.3 \mathrm{~kg} \cdot \mathrm{ha}^{-1} \mathrm{~N}, N$ - diethyl-2-(1-naphthalenyloxy) propanamide (napropamide) and $4.7 \mathrm{~kg} \cdot \mathrm{ha}^{-1} \mathrm{~S}$-propyl butylethylcarbamothioate (pebulate), and with postemergence applications of $0.56 \mathrm{~kg} \cdot \mathrm{ha}^{-1} 4$-amino-6-(1,1, dimethylethyl)-3(methylthio)-1,2,4-triazin-5(4H)-one (metribuzin) and 0.2 $\mathrm{kg} \cdot \mathrm{ha}^{-1}$ 2-[1-(ethoxyimino)butyl]-5-[2-(ethylthio)propyl]-3-hydroxy-2-cyclohexen-1-one (sethoxydim). The hairy vetch system required only the postemergence application. In the second and third years, only the postemergence herbicides were applied to all systems. Insects and pathogens were controlled in all systems by spraying as described by Abdul-Baki et al. (1992).

Tomatoes were harvested regularly at the breaker to firm-ripe stage from 8 July to 26 Aug. 1991, from 15 July to 2 Sept. 1992, and from 15 July to 9 Sept. 1993. Damaged and diseased fruit were culled, and only marketable tomatoes are reported in the yields. The fruit were not graded by size.

Economic analysis. The primary objective of the economic analysis is to determine the relative profitability of the three mulch systems under conditions commonly faced by tomato growers in the mid-Atlantic region. Tomato production typically is characterized by high variability in terms of yields across farms and of selling prices from week to week. Weekly prices for all 3 years are available from two different markets, the Southern Maryland Regional Farmers' Market in Cheltenham, Md., and the Baltimore Fresh Fruit and Vegetable Wholesale Market in Jessup, Md.
Weekly prices at Jessup are median prices for Maryland large tomatoes, while weekly prices at Cheltenham are weighted average prices for all tomato sizes. Secondary objectives of this analysis are 1) to investigate the relative profitabilities for tomato growers selling in these two markets and 2) to assess the relative risk of the three systems and the relative risk of selling in the two markets.

The tomato yields used in the analysis are the yields of the experimental plots. However, because these are typically at the high end of the yields realized by farmers, the results are subjected to sensitivity analysis for expected, optimistic, and pessimistic yields. Since using black polyethylene mulch is the most common practice for staked tomatoes, it is considered the basis for the calculation of yield adjustment factors to maintain the relative differences in yields across treatments. Experimental yields are considered optimistic yields, and expected and pessimistic yields are estimated based on published enterprise budgets from Maryland, Delaware, and Virginia (Kee et al., 1992; O'Dell et al., 1992; Univ. of Maryland, 1992). Only the Virginia budgets distinguish between stringweave (staked and tied) and ground-grown tomatoes; hence, the yield estimates here follow those of the Virginia stringweave budget most closely. Yield estimates might be lower for Maryland and Delaware since environmental conditions are different. An optimistic yield level would be 7500 boxes or 85 $\mathrm{t} \cdot \mathrm{ha}^{-1}$, which is similar to the experimental yields for black polyethylene. A more realistic or expected yield would be 6000 boxes, or $68 \mathrm{t} \cdot \mathrm{ha}^{-1}$, which is $80 \%$ of the optimistic yield, while 4500 boxes $(51 \mathrm{t})$ per hectare, or $60 \%$ of optimistic, would be considered a poor or pessimistic yield. Thus, the yields from the experiments are multiplied by 0.8 and 0.6 , respectively, to arrive at expected and pessimistic yields for the sensitivity analysis. State average yields for Maryland are considerably lower than these, but reflect a preponderance of less intensively managed, ground-grown systems.

Gross returns are calculated in this paper by matching the actual weekly harvested tomatoes with the appropriate weekly price summed over the total number of harvests for each of the 3 years. This approach is preferred to using total yield and average price because it most closely represents the reality faced by farmers and allows us to see the differences in returns that might appear as a result of differences in weekly production among the systems. This is important if one system has better early or late yields when prices may be higher.

Production costs for staked and tied tomatoes are derived from vegetable crop budgets for Maryland, Delaware, and Virginia (Kee et al., 1992; O’Dell et al., 1992; Univ. of Maryland, 1992), and are presented in Table 1. Field operations and amounts of chemical inputs used reflect actual operations at the experimental site. Fertilizer costs represent the amounts typically used in the mid-Atlantic region, with the vetch system receiving only half the typical rate of nitrogen. Machinery, labor, and fixed costs are calculated from state crop budgets and reflect those realistically faced by farmers. Prices for chemicals are the March 1994 prices from Southern States Cooperative in Baltimore and are deflated for earlier years to reflect rising input prices over time. Labor charges are \$6.00/h in 1993 and are similarly deflated for earlier years. Input costs are based on indices of production costs taken from Agricultural Statistics 1993 (USDA, 1993). Index numbers for 1991 and 1992 are published, while those for 1993 and 1994 are estimated from recent trends. Agrichemical prices and wages exhibited the most change. Chemical input costs indices are (1994 $=100)$ 96, 93, and 88 for 1993, 1992, and 1991 respectively, and wage indices are 100, 98, and 94 for the respective years. General 
Table 1. 1993 Production costs (excluding land rent and depreciation on buildings) for 1 ha of staked fresh-market tomatoes under the expected yield scenario $(80 \%$ of experimental yields).

\begin{tabular}{|c|c|c|c|}
\hline Production costs & Bare soil & Black polyethylene & Hairy vetch \\
\hline Bed preparation $(4.5 \mathrm{~h})$ & $\$ 27$ & $\$ 27$ & $\$ 27$ \\
\hline Plant hairy vetch seed (53 kg @ \$1.59) & & & 84 \\
\hline labor $1.25 \mathrm{~h}$ & & · & 8 \\
\hline Mow vetch $(2.5 \mathrm{~h})$ & & & 15 \\
\hline *Polyethylene mulch (10 rolls @ \$82 ea.) & & 820 & \\
\hline labor $10 \mathrm{~h}$ & & 60 & \\
\hline *Tomato seedlings $(13,600 @ \$ 0.07$ ea.) & 952 & 952 & 952 \\
\hline labor $50 \mathrm{~h}$ & 300 & 300 & 300 \\
\hline *Fertilizers ( $1 / 2 \mathrm{~N}$ for vetch system) & 232 & 232 & 202 \\
\hline *Postemergence herbicides & 35 & 35 & 35 \\
\hline labor $2.5 \mathrm{~h}$ & 15 & 15 & 15 \\
\hline *Pesticides (insecticides and fungicides) & 560 & 560 & 560 \\
\hline labor $25 \mathrm{~h}$ (weekly applications) & 150 & 150 & 150 \\
\hline \multicolumn{4}{|l|}{ Staking/tieing } \\
\hline *stakes (740 (3700/5 year) @ \$0.50 ea.) & & & \\
\hline and twine $(112 \mathrm{~kg})$ & 520 & 520 & 520 \\
\hline labor $90 \mathrm{~h}$ & 540 & 540 & 540 \\
\hline Irrigation (drip system) & 1400 & 1400 & 1400 \\
\hline Machinery costs (various per-hour costs) & 925 & 1035 & 975 \\
\hline \multicolumn{4}{|l|}{ Harvest } \\
\hline *boxes@\$0.85 & 4637 & 5282 & 5751 \\
\hline labor $200 \mathrm{~h}+0.1 \mathrm{~h} / \mathrm{box}$ over 1300 boxes & 3693 & 4148 & 4480 \\
\hline \multicolumn{4}{|l|}{ Marketing (hauling, grading, } \\
\hline and cooling@\$1.30/box) & 7093 & 8078 & 8796 \\
\hline Mulch removal/disposal & & 370 & \\
\hline Postharvest labor $(45 \mathrm{~h})$ & 270 & 270 & 270 \\
\hline Interest on * items above ( $12 \%$ p.a. for 6 months) & 416 & 504 & 481 \\
\hline Total production costs & $\$ 21,766$ & $\$ 25,299$ & $\$ 25,560$ \\
\hline
\end{tabular}

agricultural production costs increased slightly over this time period, and are indexed at 100, 99, and 98 for 1993, 1992, and 1991, respectively. Seed and fertilizer costs remained constant over this period, as did interest rates, and therefore are not deflated. Interest on certain operating expenses is for six months at $12 \%$ per annuum. Harvest and marketing costs change with varying yield levels. Table 1 depicts the situation of the expected yield scenario $(80 \%$ of experimental yields) in 1993. Land rent and depreciation on buildings are not included since they would be the same for all systems.

Farming, particularly vegetable production, is characterized by a high level of risk due to yield and price variability. One of the reasons for the popularity of agrichemicals is that they reduce yield variability, allowing farmers to control their production environment. Practices that replace agrichemicals must be profitable and should not increase production risk. In this study, risk is examined using a safety-first criterion, which focuses on the probability of achieving a target minimum level of returns. The safety-first rule is consistent with maximizing expected profits, where profits are a proxy for utility (Selley, 1984). Risk-averse decision makers are willing to forgo the opportunity for higher profits to achieve greater stability of income, while risk-neutral behavior is characterized by decisions based on highest expected returns without regard for potential variability. Most individuals exhibit at least mildly risk-averse behavior.

A method for using a safety-first rule was formulated by Musser et al. (1981), and used in a study involving replicated experimental data by Hanson et al. (1993). Typically, risk-averse farmers might want to be sure that, for example, in 3 out of 4 years or 9 out of 10 years, returns are expected to exceed a certain lower limit. This coincides respectively with a $75 \%$ and a $90 \%$ lower confidence interval. A lower confidence level for practice $i$ at the desired probability level, $\mathrm{Pr}$, may be defined by

$$
\mathrm{L}_{\mathrm{i}}(P r)=\mathrm{E}_{\mathrm{i}}-\mathrm{K}(P r) \mathrm{s}_{\mathrm{i}}
$$

where $\mathrm{E}_{\mathrm{i}}=$ expected returns of practice $i, \mathrm{~s}_{\mathrm{i}}=$ standard deviation of returns for practice $i$ calculated over all years and replications, and $\mathrm{K}=$ the number of standard deviations required to impose the probability, $\mathrm{Pr}$, that $\mathrm{E}_{\mathrm{i}}$ is greater than $\mathrm{L}_{\mathrm{i}}$.

The sample size for each treatment is the total number of replications in all 3 years, and is 28 for the bare soil and hairy vetch systems and 24 for the black polyethylene system. We assume that returns are normally distributed. At the $75 \%$ confidence level, $\mathrm{K}$ is 0.683 for bare soil and hairy vetch systems and 0.684 for black polyethylene. The respective values for $\mathrm{K}$ at the $90 \%$ level are 1.314 and 1.319 . In the risk analysis of the market choice, the expected (mean) returns and the standard deviation of returns are calculated separately for each system, then averaged across systems to isolate market variability from variability across systems. Sample size was 80, and the values of $\mathrm{K}$ at $75 \%$ and $90 \%$ probability are 0.678 and 1.295 respectively.

\section{Results}

Field experiments. The detailed results of the 1991 field experiment are reported in Abdul-Baki and Teasdale (1993), and the results of the 1992 and 1993 experiments are from unpublished data. Total yields for the three systems in each of the 3 years are reported in Table 2. Only the yields for the replications in which tomatoes were staked are included in this analysis to preserve consistency over the 3 years. 
Table 2. Total tomato yields for each of the three systems.

\begin{tabular}{lccl}
\hline \hline & \multicolumn{3}{c}{ Yield $^{2}\left(\mathrm{t} \cdot \mathrm{ha}^{-1}\right)$} \\
\cline { 2 - 4 } System & 1991 & 1992 & 1993 \\
\hline Bare soil & $53.4 \mathrm{c}$ & $35.5 \mathrm{~b}$ & $77.3 \mathrm{~b}$ \\
Black polyethylene & $107.3 \mathrm{~b}$ & $45.3 \mathrm{~b}$ & $88.0 \mathrm{ab}$ \\
Hairy vetch & $129.2 \mathrm{a}$ & $85.8 \mathrm{a}$ & $95.8 \mathrm{a}$
\end{tabular}

$\overline{\overline{ }}$ Values followed by the same letter within year are not significantly different according to Fisher's LSD test $(\mathrm{P}=0.05)$.

The 3 years of the experiments provided a wide contrast in growing conditions. The first year, 1991, was the best weatherwise, with high temperattires, good radiation, and a good distribution of rainfall. The second year was characterized by cool temperatures, low radiation, and higher rainfall, especially during the establishment period. This resulted in higher disease pressure in the baresoil and polyethylene systems because of splashing, the effect of which is reduced in the vetch mulch system. High temperatures, high radiation, and lack of rainfall, particularly during the growth period, characterized 1993. These conditions tended to favor the black polyethylene system.

Economic analysis. Tomato prices varied considerably from

a. 1991 WEEKLY PRICES

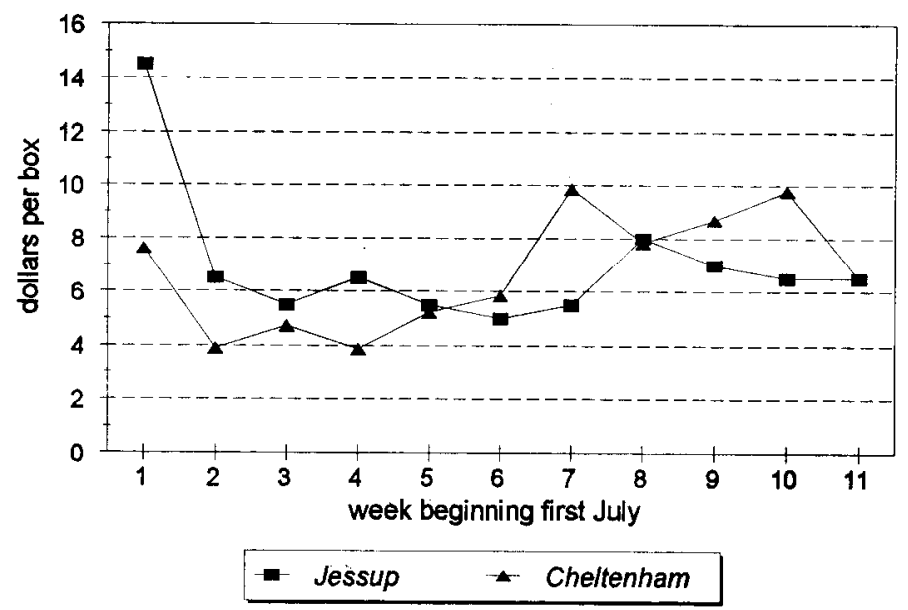

b. 1992 WEEKLY PRICES

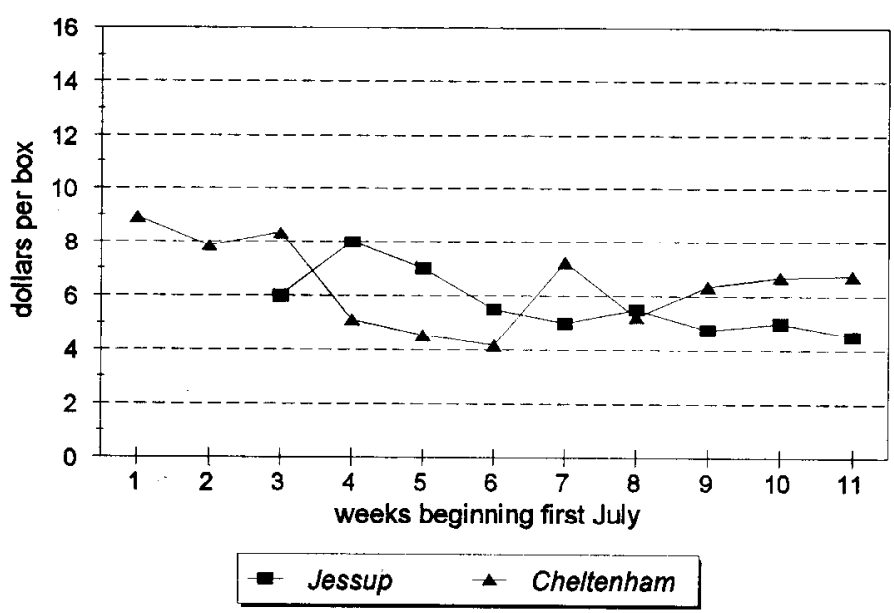

Fig. 1. Weekly tomato prices at Jessup and Cheltenham (Md.) markets. week to week and between the two markets (Fig. 1). On average, Jessup prices were higher than those of Cheltenham, although Cheltenham prices increased toward the end of the season relative to Jessup prices. The 3-year average median price for Maryland large tomatoes during this 11 -week period was $\$ 7.06 /$ box at Jessup, while the Average weighted mean tomato price at Cheltenham was $\$ 6.25 /$ box. The Jessup average weekly price over the 3 years was higher 6 out of 9 weeks (Fig. 1d).

Table 2 shows that tomatoes grown with hairy vetch mulch outyielded those grown with black polyethylene and no mulch in all 3 years. Only in 1993 were the vetch and black polyethylene yields statistically similar. Partial budget analysis reveals that hairy vetch was also the more profitable alternative in all years under all marketing and yield scenarios. These results are presented in Tables 3-5. When experimental (optimistic) yields are used, returns in the 2 good years (1991 and 1993) averaged 47\% higher under vetch than under polyethylene. And in 1992 (a poor growing year), the differences between the returns from the vetch and polyethylene systems were actually greater than in the better years. Even in 1993, when the black polyethylene yields were statistically similar to those from the vetch system, returns under the vetch system ranged from $25 \%$ to $60 \%$ higher than those under the

\section{c. 1993 WEEKLY PRICES}

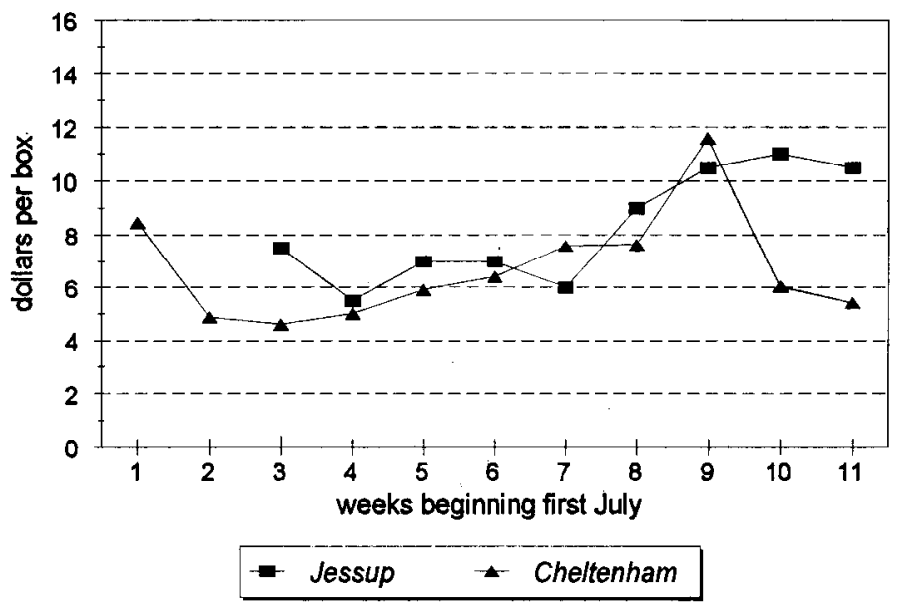

d. AVERAGE WEEKLY PRICES, 1991-93

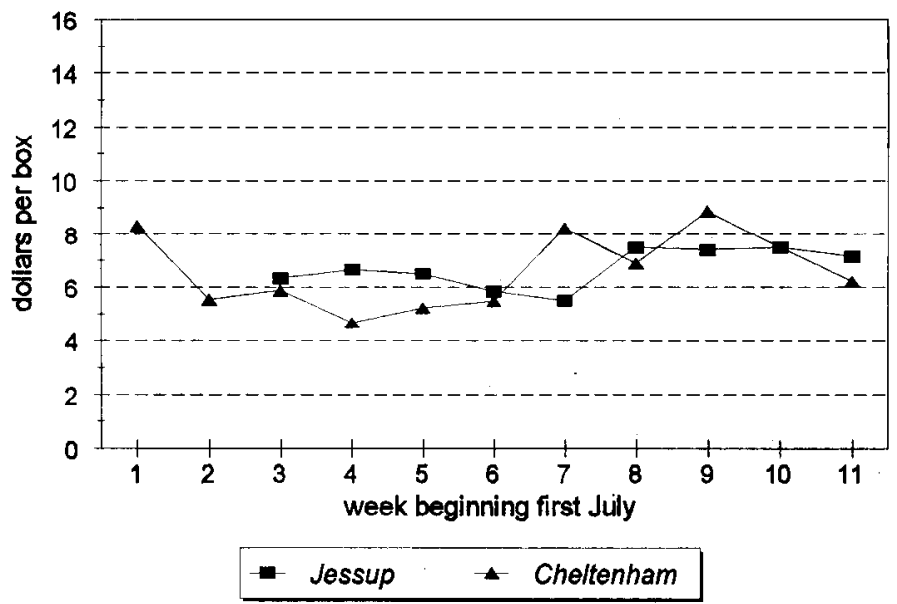


Table 3. 1991 returns to management, land, and buildings (\$/ha).

\begin{tabular}{|c|c|c|c|c|c|c|}
\hline & \multicolumn{3}{|c|}{ Jessup market } & \multicolumn{3}{|c|}{ Cheltenham market } \\
\hline & $\begin{array}{l}\text { Bare } \\
\text { soil }\end{array}$ & $\begin{array}{c}\text { Black } \\
\text { polyethylene }\end{array}$ & $\begin{array}{l}\text { Hairy } \\
\text { vetch }\end{array}$ & $\begin{array}{c}\text { Bare } \\
\text { soil }\end{array}$ & $\begin{array}{c}\text { Black } \\
\text { polyethylene }\end{array}$ & $\begin{array}{l}\text { Hairy } \\
\text { vetch }\end{array}$ \\
\hline \multicolumn{7}{|c|}{ Optimistic yields (experimental plots) } \\
\hline Yields $\left(t \cdot h a^{-1}\right)$ & 53.4 & 107.3 & 129.2 & 53.4 & 107.3 & 129.2 \\
\hline Gross returns & $\$ 26,419$ & $\$ 53,640$ & $\$ 62,366$ & $\$ 24,158$ & $\$ 47,339$ & $\$ 64,186$ \\
\hline Production costs & $\$ 19,111$ & $\$ 33,430$ & $\$ 37,305$ & $\$ 19,111$ & $\$ 33,430$ & $\$ 37,305$ \\
\hline Returns to land, bldgs., mgt. & $\$ 7,308$ & $\$ 20,210$ & $\$ 25,060$ & $\$ 5,047$ & $\$ 13,909$ & $\$ 26,880$ \\
\hline \multicolumn{7}{|c|}{ Expected yields ( $80 \%$ of experimental plots) } \\
\hline Yields $\left(t \cdot h a^{-1}\right)$ & 42.7 & 85.9 & 103.3 & 42.7 & 85.9 & 103.3 \\
\hline Gross returns & $\$ 21,135$ & $\$ 42,912$ & $\$ 49,893$ & $\$ 19,327$ & $\$ 37,872$ & $\$ 51,349$ \\
\hline Production costs & $\$ 16,551$ & $\$ 28,286$ & $\$ 31,114$ & $\$ 16,551$ & $\$ 28,286$ & $\$ 31,114$ \\
\hline Returns to land, bldgs., mgt. & $\$ 4,584$ & $\$ 14,626$ & $\$ 18,778$ & $\$ 2,775$ & $\$ 9,585$ & $\$ 20,234$ \\
\hline \multicolumn{7}{|c|}{ Pessimistic yields ( $60 \%$ of experimental plots) } \\
\hline Yields (t.ha $\left.{ }^{1}\right)$ & 32 & 64.4 & 77.5 & 32 & 64.4 & 77.5 \\
\hline Gross returns & $\$ 15,852$ & $\$ 32,184$ & $\$ 37,419$ & $\$ 14,495$ & $\$ 28,404$ & $\$ 38,511$ \\
\hline Production costs & $\$ 13,992$ & $\$ 23,142$ & $\$ 24,923$ & $\$ 13,992$ & $\$ 23,142$ & $\$ 24,923$ \\
\hline Returns to land, bldgs., mgt. & $\$ 1,860$ & $\$ 9,042$ & $\$ 12,496$ & $\$ 503$ & $\$ 5,261$ & $\$ 13,588$ \\
\hline
\end{tabular}

Table 4. 1992 returns to management, land, and buildings (\$/ha).

\begin{tabular}{|c|c|c|c|c|c|c|}
\hline & \multicolumn{3}{|c|}{ Jessup market } & \multicolumn{3}{|c|}{ Cheltenham market } \\
\hline & $\begin{array}{c}\text { Bare } \\
\text { soil }\end{array}$ & $\begin{array}{c}\text { Black } \\
\text { polyethylene }\end{array}$ & $\begin{array}{l}\text { Hairy } \\
\text { vetch }\end{array}$ & $\begin{array}{c}\text { Bare } \\
\text { soil }\end{array}$ & $\begin{array}{c}\text { Black } \\
\text { polyethylene }\end{array}$ & $\begin{array}{l}\text { Hairy } \\
\text { vetch }\end{array}$ \\
\hline \multicolumn{7}{|c|}{ Optimistic yields (experimental plots) } \\
\hline Yields $\left(t \cdot h a^{-1}\right)$ & 35.5 & 45.3 & 85.8 & 35.5 & 45.3 & 85.8 \\
\hline Gross returns & $\$ 18,290$ & $\$ 24,604$ & $\$ 41,957$ & $\$ 15,822$ & $\$ 19,612$ & $\$ 42,253$ \\
\hline Production costs & $\$ 15,050$ & $\$ 18,824$ & $\$ 27,469$ & $\$ 15,050$ & $\$ 18,824$ & $\$ 27,469$ \\
\hline Returns to land, bldgs., mgt. & $\$ 3,240$ & $\$ 5,781$ & $\$ 14,488$ & $\$ 773$ & $\$ 789$ & $\$ 14,784$ \\
\hline \multicolumn{7}{|c|}{ Expected yields ( $80 \%$ of experimental plots) } \\
\hline Yields $\left(l \cdot h \mathbf{a}^{-1}\right)$ & 28.4 & 36.2 & 68.7 & 28.4 & 36.2 & 68.7 \\
\hline Gross returns & $\$ 14,632$ & $\$ 19,684$ & $\$ 33,566$ & $\$ 12,658$ & $\$ 15,690$ & $\$ 33,802$ \\
\hline Production costs & $\$ 13,313$ & $\$ 16,611$ & $\$ 23,273$ & $\$ 13,313$ & $\$ 16,611$ & $\$ 23,273$ \\
\hline Returns to land, bldgs., mgt. & $\$ 1,319$ & $\$ 3,072$ & $\$ 10,292$ & $(\$ 655)$ & $(\$ 921)$ & $\$ 10,529$ \\
\hline \multicolumn{7}{|c|}{ Pessimistic yields ( $60 \%$ of experimental plots) } \\
\hline Yields $\left(\mathrm{t} \cdot \mathrm{ha}^{-1}\right)$ & 21.3 & 27.2 & 51.5 & 21.3 & 27.2 & 51.5 \\
\hline Gross returns & $\$ 10,974$ & $\$ 14,763$ & $\$ 25,174$ & $\$ 9,493$ & $\$ 11,767$ & $\$ 25,352$ \\
\hline Production costs & $\$ 11,577$ & $\$ 14,399$ & $\$ 19,078$ & $\$ 11,577$ & $\$ 14,399$ & $\$ 19,078$ \\
\hline Returns to land, bldgs., mgt. & $(\$ 603)$ & $\$ 364$ & $\$ 6,097$ & $(\$ 2,083)$ & $(\$ 2,631)$ & $\$ 6,274$ \\
\hline
\end{tabular}

polyethylene system, depending on the scenario. The average returns for all 3 years under the different yield scenarios are presented in Table 6.

The higher relative profitability of the vetch system was due in part to higher yields with a lower cost structure and to higher lateseason prices. Although tomatoes grown with black polyethylene mature more quickly and provide earlier yields when prices might be higher, in this particular case, the later-yielding hairy vetch system took advantage of the higher prices later in the season.

Choice of market also made a difference with respect to the different systems. In all 3 years, the profitability of the black polyethylene system was greater when the tomatoes were sold in the Jessup market because of the higher earlier prices this market seemed to offer. On the other hand, in 2 out of 3 years, returns under the hairy vetch system were greater when the tomatoes were sold in the Cheltenham market. Only in 1993 was the Jessup market clearly superior.
Results of the sensitivity analysis reveal that, even under the pessimistic scenario, the hairy vetch mulch system returned a reasonable profit in both marketing situations, exceeding $\$ 12,000$ / ha in all but 1992, when profit dipped to just over $\$ 6,000$. The baresoil and black polyethylene systems showed losses under the expected and pessimistic yield scenarios in 1992 when the Cheltenham market was used, and the bare-soil system also showed a loss under the 1992 pessimistic scenario using the Jessup market. In all other years and situations, all systems showed a profit.

Risk analysis revealed that hairy vetch was also the least risky of the three alternative practices. The lower limits of returns for each system at $90 \%$ and $75 \%$ risk confidence levels are presented in Table 7. The actual experimental yields were used in this analysis, so the results in Table 7 are representative of the optimistic scenario. These results indicate that a risk-averse farmer would prefer the hairy vetch mulch system -for growing fresh-market 
Table 5. 1993 returns to management, land, and buildings ( $\$ / \mathrm{ha})$.

\begin{tabular}{|c|c|c|c|c|c|c|}
\hline & \multicolumn{3}{|c|}{ Jessup market } & \multicolumn{3}{|c|}{ Cheltenham market } \\
\hline & $\begin{array}{c}\text { Bare } \\
\text { soil }\end{array}$ & $\begin{array}{c}\text { Black } \\
\text { polyethylene }\end{array}$ & $\begin{array}{l}\text { Hairy } \\
\text { vetch }\end{array}$ & $\begin{array}{c}\text { Bare } \\
\text { soil }\end{array}$ & $\begin{array}{c}\text { Black } \\
\text { polyethylene }\end{array}$ & $\begin{array}{l}\text { Hairy } \\
\text { vetch }\end{array}$ \\
\hline \multicolumn{7}{|c|}{ Optimistic yields (experimental plots) } \\
\hline Yields $\left(\mathrm{t} \cdot \mathrm{ha}^{-1}\right)$ & 77.2 & 88 & 95.8 & 77.2 & 88 & 95.8 \\
\hline Gross returns & $\$ 52,681$ & $\$ 57,290$ & $\$ 70,290$ & $\$ 44,156$ & $\$ 49,651$ & $\$ 55,369$ \\
\hline Production costs & $\$ 25,587$ & $\$ 29,650$ & $\$ 30,298$ & $\$ 25,587$ & $\$ 29,650$ & $\$ 30,298$ \\
\hline Returns to land, bldgs., mgt. & $\$ 27,094$ & $\$ 27,639$ & $\$ 39,992$ & $\$ 18,569$ & $\$ 20,000$ & $\$ 25,071$ \\
\hline \multicolumn{7}{|c|}{ Expected yields ( $80 \%$ of experimental plots) } \\
\hline Yields $\left(t \cdot h a^{-1}\right)$ & 61.8 & 70.4 & 76.6 & 61.8 & 70.4 & 76.6 \\
\hline Gross returns & $\$ 42,145$ & $\$ 45,832$ & $\$ 56,233$ & $\$ 35,325$ & $\$ 39,721$ & $\$ 44,295$ \\
\hline Production costs & $\$ 21,766$ & $\$ 25,299$ & $\$ 25,560$ & $\$ 21,766$ & $\$ 25,299$ & $\$ 25,560$ \\
\hline Returns to land, bldgs., mgt. & $\$ 20,379$ & $\$ 20,533$ & $\$ 30,672$ & $\$ 13,558$ & $\$ 14,422$ & $\$ 18,735$ \\
\hline \multicolumn{7}{|c|}{ Pessimistic yields ( $60 \%$ of experimental yields) } \\
\hline Yields $\left(\mathrm{l} \cdot \mathrm{ha}^{-1}\right)$ & 46.3 & 52.8 & 57.5 & 46.3 & 52.8 & 57.5 \\
\hline Gross returns & $\$ 31,609$ & $\$ 34,374$ & $\$ 42,174$ & $\$ 26,494$ & $\$ 29,790$ & $\$ 33,221$ \\
\hline Production costs & $\$ 17,946$ & $\$ 20,948$ & $\$ 20,822$ & $\$ 17,946$ & $\$ 20,948$ & $\$ 20,822$ \\
\hline Returns to land, bldgs., mgt. & $\$ 13,663$ & $\$ 13,426$ & $\$ 21,352$ & $\$ 8,548$ & $\$ 8,843$ & $\$ 12,399$ \\
\hline
\end{tabular}

tomatoes under the conditions presented in this study. Market choice analysis showed that the Jessup market is the preferred market for the risk-averse farmer (Table 8).

\section{Discussion}

As vegetable production becomes more competitive with vegetables being transported across country and with international trade in vegetables increasing, the profitability of local vegetable production is increasingly important if local producers are to remain viable. The chief competitors of tomato producers in the mid-Atlantic and northeastern regions are no longer their neigh-

Table 6. Average annual returns per hectare under different yield scenarios.

\begin{tabular}{lccc}
\hline \hline & \multicolumn{3}{c}{ Yield scenario } \\
\cline { 2 - 4 } System & Optimistic & Expected & Pessimistic \\
\hline Bare soil & $\$ 10,339$ & $\$ 6,993$ & $\$ 3,648$ \\
Black polyethylene & $\$ 14,721$ & $\$ 10,219$ & $\$ 5,717$ \\
Hairy vetch & $\$ 24,379$ & $\$ 18,207$ & $\$ 12,034$ \\
\hline
\end{tabular}

Table 7. Lower limit of returns per hectare for each system at $90 \%$ and $75 \%$ risk confidence levels.

\begin{tabular}{lcr}
\hline \hline & \multicolumn{2}{c}{ Confidence level } \\
\cline { 2 - 3 } System & $90 \%$ & $75 \%$ \\
\hline Bare soil & $\$ 2,500)$ & $\$ 3,269$ \\
Black polyethylene & $\$ 3,365$ & $\$ 8,962$ \\
Hairy vetch & $\$ 11,858$ & $\$ 18,021$ \\
\hline
\end{tabular}

Tables. Lower limit of returns per hectare for each market at $90 \%$ and $75 \%$ risk confidence levels.

\begin{tabular}{lcr}
\hline \hline & \multicolumn{2}{c}{ Confidence level } \\
\cline { 2 - 3 } Market & $90 \%$ & $75 \%$ \\
\hline Jessup & $\$ 5,346$ & $\$ 11,684$ \\
Cheltenham & $\$ 4,684$ & $\$ 9,194$ \\
\hline
\end{tabular}

bors or even the growers in neighboring states, but producers in California and in Mexico and other countries. Couple this with rising environmental concerns, and the need for highly profitable yet environmentally friendly production systems is all too evident. The hairy vetch mulch production system for fresh-market tomatoes appears to fill this need.

Returns to land, buildings, and management from the hairy vetch system were consistently higher and less risky than those from the black polyethylene system, which is considered the industry standard. The profitability advantage of the vetch system is due to generally higher yields and to later production, which coincided with higher late-season prices. The relative importance of these two reasons varies from year to year. For example, high late-season prices in 1993, particularly in the Jessup market, resulted in the higher returns for the vetch system, whereas higher yields boosted vetch system returns in 1992 when prices were relatively constant. More years of analyses will be required to understand the relative strengths of these two factors. The price advantage in particular could be expected to diminish as more growers adopt the hairy vetch mulch system. If that happens, the earliness attribute of the black polyethylene will become more important, particularly in the cooler areas of the northeastern United States.

The hairy vetch mulch system does require a longer season than is required for growing tomatoes without an organic mulch. This would be a disadvantage in cooler climates. In central Maryland, the vetch must be planted by late September to take full advantage of its benefits. This means that the preceding crop must be harvested and removed by mid-September so that the beds can be prepared for planting vetch. Depending on the previous crop, this might pose a labor or equipment constraint for some farmers. Also, the vetch requires some warm days in the spring when most of its growth occurs. Ideally, the vetch should flower before it is mowed to discourage regrowth. Thus, the advantages discussed in this paper may not hold for regions with shorter growing seasons.

In addition to the economic advantages of the hairy vetch system, it has obvious environmental advantages as well. An overwintering cover crop can tie up nitrogen that would otherwise be lost when the previous crop is removed. Vetch's nitrogen fixing capabilities reduce or perhaps even eliminate the need for added inorganic nitrogen to the succeeding tomato crop. And the mulch 
cover provided by the vetch keeps the soil cooler and wetter during the hot summer months as well as reducing erosion. Finally, the organic mulch system eliminates the need to use polyethylene mulch, which is not only expensive, but presents a waste disposal problem as well (Servis, 1992). The combination of environmental benefits as well as the economic benefits to the grower make the hairy vetch mulch system an attractive alternative for the production of fresh-market tomatoes in the mid-Atlantic region and in parts of northeastern United States.

\section{Literature Cited}

Abdul-Baki, A., C. Spence, and R. Hoover. 1992. Black polyethylene mulch doubled yield of fresh-market field tomatoes. HortScience 27:787789 .

Abdul-Baki, A.A. and J.R. Teasdale. 1993. A no-tillage tomato production system using hairy vetch and subterranean clover mulches. HortScience 28:106-108.

Buttel, F.H., M. Lancelle, and D.R. Lee. 1988. Farm structure and rural communities in the northeast. In: Louis E. Swanson (ed.). Agriculture and community change in the U.S. Westview Press, Boulder, Colo.

Hanson, J.C., E. Lichtenberg, A.M. Decker, and A.J. Clark. 1993. Profitability of no-tillage corn following a hairy vetch cover crop. J. Prod. Agr. 6(3):432-437.

Kee, E., T. Wootten, and L. Lillard. 1992. Vegetable crop budget, 19901992. Extension Circular 152. Delaware Coop. Ext., Univ. of Delaware and Delaware State College.
Lu, Y.-C. and T.C. Kelly. 1995. Implications of sustainable agriculture for the world food situation. Food Rev. Intl. 11(2):255-280.

Musser, W.N., J. Ohannesian, and F.J. Benson. 1981. A safety-first model of risk management for use in extension programs. North Central J. Agr. Econ. 3(1):41-46.

O’Dell, C., H. Snodgrass, and G. Groover. 1992. 44 selected costs and returns budgets for horticultural food crops production/marketing. Publication 438-898, Virginia Coop. Ext., Virginia Polytechnic Inst. and State Univ., Blacksburg.

Selley, R. 1984. Decision rules in risk analysis. In: Peter J. Barry (ed.). Risk management in agriculture. Iowa State Univ. Press, Ames.

Servis, R. 1992. Ag plastic recycling on horizon. Florida Grower and Rancher 85(3):40.

Teasdale, J.R. and D. Colacicco. 1985. Weed control systems for fresh market tomato production on small farms. J. Amer. Soc. Hort. Sci. 110:533-537.

United States Department of Agriculture (USDA), Economic Research Service. 1992. Americans are eating more fruits and vegetables. Farmline 13(7):8-13.

United States Department of Agriculture (USDA), National Agricultural Statistics Service. 1993. Agricultural Statistics 1993. U.S. Govt. Printing Office, Washington, D.C.

University of California. 1993. Progress Report, 1990-1993, of the UC Sustainable Agriculture Research and Education Program. Univ. of California, Davis.

University of Maryland. 1992. Maryland crop budgets. Dept. of Agr. and Resource Econ. and Maryland Coop. Ext. Serv., College Park. 